\title{
ITIKAD BAIK DALAM PENDAFTARAN MEREK TERKENAL DI INDONESIA
}

\author{
Farly Lumopa, Suherman dan Imam Haryanto \\ Fakultas Hukum Universitas Pembangunan Nasional Veteran Jakarta \\ Email : suherman_upn@yahoo.com
}

\begin{abstract}
Abstrak
Itikad baik dalam pendaftaran merek merupakan awal dari diajukannya permohonan pendaftaran merek dan merek terkenal di Indonesia. Hal ini sesuai dengan Pasal 4 Undang-undang nomor 15 tahun 2001 yaitu merek tidak dapat didaftar atas dasar Permohonan yang diajukan oleh Pemohon yang beritikad tidak baik. Penelitian ini diharapkan memberikan pengetahuan umum yang dapat memberikan gambaran yang jelas tentang itikad baik dalam pendaftaran merek terkenal di Indonesia.

Target khusus yang ingin dicapai adalah konsep itikad baik yang diatur dalam hukum positif di Indonesia dan perkembangannya dari konsep itikad baik. Sehingga akan memberikan pemahaman yang jelas tentang itikad baik dalam pendaftaran merek dan merek terkenal di Indonesia.
\end{abstract}

\section{Kata kunci : Itikad baik, Pendaftaran merek, merek.}

\begin{abstract}
Good faith in trademark registration is the beginning of the application for registration of famous brands and brands in Indonesia. In accordance with Article 4 of Act No. 15 of 2001, represent that a mark cannot be registered on the basis of an Application submitted by the Applicant with a bad faith. This research is expected to provide general knowledge that can provide a general description of good faith in the registration offamous brands and brands in Indonesia.

Specific targets to be achieved are the concept of good faith regulated in positive law in Indonesia and its development from the concept of good faith. So that it will provide a clear understanding of good faith in the registration of famous brands and brands in Indonesia.
\end{abstract}

\section{Keywords: Good faith, Registration of trademark,brand}

\section{A. PENDAHULUAN}

\section{Latar Belakang}

Merek memiliki peranan penting dalam perkembangan dunia usaha. Saat ini merek telah menjadi suatu gengsi bagi masyarakat dan gengsi seseorang terletak pada barang yang dipakai atau jasa yang digunakan. Terkadang merek menjadi gaya hidup (lifestyle), merek bisa membuat seseorang meningkatkan rasa percaya diri atau menentukan kelas sosial mereka.

Beragamnya merek produk yang ditawarkan oleh produsen kepada konsumen menjadikan konsumen dihadapkan pada berbagai macam pilihan, bergantung kepada 
daya beli atau kemampuan konsumen. Masyarakat menengah ke bawah yang tidak ingin ketinggalan menggunakan barang-barang merek terkenal dengan membeli barang yang palsu. Walaupun barangnya palsu, imitasi dan bermutu rendah tidak menjadi masalah bagi mereka, asalkan barang dengan merek tersebut dapat terbeli. Dengan terjadinya pemalsuan merek, perdagangan tentunya tidak akan berkembang dengan baik dan akan semakin memperburuk citra Indonesia sebagai pelanggar Hak Kekayaan Intellectual (HKI). Merek sama halnya dengan bidang HKI lainnya, tidak hanya sebagai bagian dari sistem perdagangan domestik, tapi juga bagian dari sistem perdagangan internasional. Dalam kaitannya dengan sistem perdagangan internasional diperlukan adanya suatu merek yang diakui dibanyak negara. Merek terkenal asing atau merek terkenal yang berasal dari luar negeri atau dengan kata lain pemilik merek terkenal yang terdaftar merupakan pihak asing baik pribadi maupun badan hukum. Wujud persaingan curang yang biasanya dialami oleh merek terkenal berupa peniruan. ${ }^{1}$

Kerugian yang ditimbulkan oleh merek tiruan juga dirasakan oleh konsumen. Merek tiruan sebahagian besar memilki kualitas rendah. Konsumen yang hendak membeli barang dengan merek terkenal akan terkecoh dan pada akhirnya membeli barang yang menggunakan merek tiruan sehingga konsumen tidak menikmati barang dengan kualitas tinggi yang biasa diperolehnya dari konsumsi terhadap barang yang menggunakan merek terkenal. Persoalan ini berkaitan dengan kerugian lainnya yang dialami pemilik merek terkenal yakni adanya penurunan kepercayaan konsumen terhadap kualitas merek terkenal sekaligus tercemarnya nama baik pemilik merek terkenal atas kualitas barang yang diproduksi. ${ }^{2}$

Peniruan yang dilakukan bukan saja merugikan pihak pemilik merek terkenal dan konsumen, tetapi juga secara meluas merugikan masyarakat Indonesia, karena dengan adanya peniruan dapat mematikan daya kreasi manusia dalam menciptakan sebuah karya baru. Perkembangan motif pelanggaran terhadap merek mengacu pada peniruan merek terkenal yang tidak hanya untuk barang identik atau mirip (identical or similar goods), tapi juga meluas hingga peniruan merek terkenal untuk merek jasa (services)

\footnotetext{
${ }^{1}$ Jisia Mamahit, PerlindunganHukumAtasMerekDalamPerdaganganBarang Dan Jasa, http://ejournal.unsrat.ac.id/index.php/lexprivatum/article/, diaksespadatanggal 23November2017 ${ }^{2}$ Ibid
} 
dan untuk merek barang yang tidak sejenis atau tidak mirip (goods or services which are not similar). ${ }^{3}$

Pada saat produsen telah berhasil memproduksi barang atau jasa dengan merek yang dikenal dan dibeli oleh konsumen, karena reputasi, kualitas, dan image serta telah dipasarkan secara luas baik nasional maupun internasional, sering kali produsen juga mendaftarkan merek yang sudah terkenal tersebut untuk jenis dan kelas barang atau jasa lain.

Dampak buruk dari pelanggaran terhadap pelanggaran merek terkenal mengkhawatirkan masyarakat internasional sehingga negara-negara berinisiatif untuk berkumpul dan berunding demi tercapainya kesepakatan dalam perjanjian internasional yang khusus memberikan perlindungan hukum terhadap merek terkenal. Ketentuan hukum yang dimaksud tertulis dalam Pasal 6 bis ayat (1) Konvensi Paris dengan rumusan pasal sebagai berikut:

"the countries of the Union undertake, ex officio if their legislation so permits, or at the request of an interested party, to refuse or to cancel the registration, and to prohibit the use, of a trademark which constitutes a reproduction, an imitation, or a translation, liable to create confusion, of a mark considered by the competent authority of the country of registration or use to be well-known in that country as being already the mark of a person entitled to the benefits of this Convention and used for identical or similiar goods. These provosions shall also apply when the essential part of the mark constitutes a reproduction of any such well-known mark or an imitation liable to create confusion therewith.",4

Dengan telah diratifikasinya Konvensi Paris oleh pemerintah Indonesia melalui Keppres No. 15 Tahun 1997, maka pelanggaran terhadap merek dengan merek terkenal sebagai target untuk barang identik atau mirip (identical or similar goods) memperoleh

\footnotetext{
${ }^{3}$ Penggunaan kata "identical or similar" dalam ketentuan di Konvensi Paris atauPersetujuan TRIPs secaraharfiahdiartikandenganidentikataumirip.Namununtukmenyesuaikandenganistilah yang digunakandalamketentuanhukumnasional, yakni yang terdapatdalam UU No. 15 Tahun 2001, "identical or similar" inidiartikandengan "sejenis"

${ }^{4}$ Terjemahan Pasal 6 bisayat (1) Konvensi Paris adalah "Negara anggota Union secaraex officio jika legislasinya mengizinkan atau atas permintaan pihak yang berkepentingan, menolak atau membatalkan pendaftaran, dan melarang penggunaan merek yang merupakan reproduksi, imitasi, atau terjemahan, yang dapat menciptakan kebingungan atas satu merek yang menurut pihak berwenang dari negara pendaftar atau penggunadari merek terkenal di negara tersebut sebagaimana yang secara sah diberikan kepada orang yang berhak berdasarkan konvensi ini dan digunakan untuk barang identik atau mirip. Ketentuan ini juga berlaku ketika bagian esensial dari merek merupakan reproduksi atau imitasi dari merek terkenal yang dapat menciptakan kebingungan."
} 
perlindungan hukum berupa penolakan atau pembatalan pendaftaran merek, dan pelarangan penggunaan merek. Undang-Undang Merek sebagai ketentuan nasional yang mengatur bidang merek telah memberikan perlindungan hukum terhadap merek terkenal berupa penolakan atau pembatalan pendaftaran merek, dan pelarangan penggunaan merek, yang diatur pada Pasal 6 ayat (1) yang rumusannya ialah "Permohonan pendaftaran merek baru yang memiliki persamaan pada pokok atau keseluruhannya harus ditolak." 5

Prinsip yang penting yang dijadikan sebagai pedoman berkenaan dengan pendaftaran merek adalah perlunya itikad baik (good faith) dari pendaftar. Berkaitan dengan itikad tidak baik, berdasarkan Undang-Undang Merek yang menganut asas First To File System bahwa hanya merek yang didaftarkan dan beritikad baik yang mendapatkan perlindungan hukum.

Secara umum, merek tidak dapat didaftar atas dasar permohonan yang diajukan oleh pemohon yang beritikad tidak baik. Pemohon yang beritikad baik adalah pemohon yang mendaftarkan mereknya secara layak dan jujur tanpa ada niat apa pun untuk membonceng, meniru, atau menjiplak ketenaran merek pihak lain demi kepentingan usahanya yang berakibat pada pihak lain itu atau menimbulkan kondisi persaingan curang, mengecoh, atau menyesatkan konsumen. ${ }^{6}$

\section{Rumusan Masalah}

Berdasarkan uraian diatas, rumusan masalah dalam penelitian ini adalah bagaimana perihal itikad baik dalam pendaftaran merek terkenal di Indonesia.

\section{B. PEMBAHASAN}

Pada hakikatnya suatu merek digunakan oleh produsen atau pemilik merek untuk melindungi produknya, baik berupa jasa atau barang dagang. Dengan didaftarkannya suatu merek, pemilik tersebut mendapat hak atas merek yang dilindungi oleh hukum. ${ }^{7}$

Perlu untuk dipahami bahwa pendaftaran merek merupakan sebuah proses yang tidak sebentar, bukan serta merta permohonan diajukan lalu merek langsung didaftar.

\footnotetext{
5. Indonesia, Undang-undang No. 15 Tahun 2001 tentang Merek.

6. Ahmd M. Ramli, 2010, Hak atas Kekayaan Intellectual (HAKI), Teori Dasar Perlindungan Rahasia Dagang, Mandar Maju, Bndung, hal. 24.

${ }^{7}$ Dwi Rezki Sri Astarini, 2009, Penghapusan Merek Terdaftar Berdasarkan UU No. 15 Tahun 2001 Tentang Merek Dihubungkan Dengan TRIPs-WTO, Alumni, Bandung, hlm. 69
} 
Saat seseorang mengajukan permohonan pendaftaran merek yang sudah dilengkapi sesuai ketentuan yang berlaku, Dirjen HKI baru akan memberikan nomor permohonan sekaligus tanggal penerimaan permohonan. ${ }^{8}$

Selanjutnya ada dua tahapan esensial yang harus dilalui oleh sebuah merek untuk bisa didaftar: ${ }^{9}$

1. Pemeriksaan substantif dimana pemeriksa merek di DJKI akan menilai apakah merek dapat diterima sesuai Pasal 4 dan 5 UU Merek, serta membandingkan merek yang akan didaftar dengan merek-merek milik orang lain yang telah terdaftar duluan, kalau-kalau terdapat persamaan baik secara keseluruhan maupun pada pokoknya sesuai Pasal 6 Undang-Undang Merek; dan

2. Pengumuman dimana masyarakat umum diberi kesempatan untuk mengajukan keberatan terhadap merek yang akan didaftar tadi.

Jika lolos dari kedua tahapan tadi barulah merek benar-benar resmi didaftar, dan selanjutnya Dirjen HKI akan segera menerbitkan sertifikat pendaftaran merek.

Pasal 3 dan Pasal 4 Undang-Undang Merek pada intinya menentukan bahwa hak atas merek merupakan hak eksklusif yang diberikan oleh negara kepada pemilik merek yang terdaftar untuk jangka waktu tertentu (jangka waktu 10 tahun sejak tanggal penerimaan permohonan) dengan menggunakan sendiri mereknya atau melisensikan kepada pihak lain dengan iktikad baik. Dengan adanya hak eksklusif atau hak khusus tersebut, orang lain dilarang menggunakan merek terdaftar untuk barang dan atau jasa yang sejenis, kecuali telah mendapat izin dari pemilik merek terdaftar. ${ }^{10}$ Sedangkan menurut P.D.D. Dermawan merek yang sudah terdaftar akan mempunyai fungsi, yaitu: ${ }^{11}$

a. Fungsi indikator sumber, artinya merek berfungsi unutk menunjukkan bahwa suatu produk bersumber secara sah pada suatu unit usaha dan karenanya juga

\footnotetext{
${ }^{8}$ Prayudi Setiadharma, Sedikit Kisah Mengenai Tentang Hapusnya Merek IKEA, http://www.hki.co.id/artikel, diakses pada 20 Maret 2018

${ }^{9}$ Ibid

${ }^{10}$ Rahmi Jened, 2015, Hukum Merek (Trademark Law) Dalam Era Global \& Integrasi Ekonomi, Kencana, Jakarta, hlm. 193

${ }^{11}$ Ok. Saidin, 2013, Aspek Hukum Hak Kekayaan Intelektual (Intellectual Property Rights), PT. RajaGrafindo Persada, Jakarta, hlm. 359. Lihat juga Ari Purwadi, Aspek Hukum Perdata Pada Perlindungan Konsumen, Yuridika, Majalah Fakultas Hukum Airlangga, Nomor 1 dan 2, Tahun VII, JanFeb-Maret, hlm. 59
} 
berfungsi untuk memberikan indikasi bahwa produk itu dibuat secara profesional;

b. Fungsi indikator kualitas, artinya merek berfungsi sebagai jaminan kualitas khususnya dalam kaitan dengan produk-produk bergengsi;

c. Fungsi sugestif, artinya merek memberikan kesan akan menjadi kolektor produk tersebut.

Tiga fungsi merek tersebut, menyebabkan perlindungan hukum terhadap merek menjadi begitu sangat bermakna.

Pasal 28 Undang-Undang Merek mengatur mengenai jangka waktu perlindungan merek terdaftar yaitu selama 10 (sepuluh) tahun sejak tanggal penerimaan dan jangka waktu itu dapat diperpanjang. Jangka waktu ini jauh lebih lama dibandingkan dengan Pasal 18 Persetujuan TRIPs yang hanya memberikan perlindungan hukum atas merek selama 7 tahun dan setelah itu dapat diperbaharui lagi. Akan tetapi, dalam jangka waktu tersebut tidak tertutup kemungkinan adanya permohonan pembatalan ataupun penghapusan merek yang telah terdaftar, jika dalam jangka waktu tersebut terdapat pelanggaran merek. ${ }^{12}$

Berdasarkan Undang-Undang Merek, Penghapusan merek terdaftar dapat dilakukan oleh 3 pihak, yaitu:

1. Penghapusan dilakukan oleh pemilik merek sendiri;

2. Penghapusan dilakukan atas prakarsa Direktorat Merek; dan

3. Penghapusan yang dilakukan atas perintah pengadilan berdasarkan gugatan dari pihak ketiga.

Pada dasarnya, penghapusan merek terdaftar dilakukan jika merek tidak digunakan secara 3 (tiga) tahun secara berturut-turut dan jika merek digunakan tidak sesuai dengan yang didaftarkan, dimana ini sesuai dengan ketentuan Pasal 61 ayat (2) Undang-Undang Merek.

Sesuai dengan fungsi merek, sebagai tanda pembeda, maka seyogianya antara merek yang dimiliki oleh seseorang tidak boleh sama dengan merek yang dimiliki oleh pihak lain. Persamaan itu tidak saja sama secara keseluruhan, tetapi memiliki persamaan

\footnotetext{
${ }^{12}$ Dwi Rezki Sri Astarini, Op.Cit., hlm. 53
} 
secara prinsip, dan yang berarti merek tersebut secara totalitas ditiru. Yang dimaksudkan dengan persamaan pada pokoknya adalah kemiripan yang disebabkan oleh adanya unsur-unsur yang menonjol antara merek yang satu dan merek yang lain, yang dapat menimbulkan kesan adanya persamaan baik mengenai bentuk, cara penempatan, cara penulisan, cara penulisan atau kombinasi antara unsur-unsur ataupun persamaaan bunyi ucapan yang terdapat dalam merek tersebut. ${ }^{13}$

Penolakan permohonan terhadap merek yang mempunyai persamaan pada pokoknya atau keseluruhan dengan merek terkenal untuk barang dan/atau jasa yang sejenis dilakukan dengan memperhatikan pengetahuan umum masyarakat mengenai merek tersebut di bidang usaha yang bersangkutan. ${ }^{14}$

Ada tiga bentuk pemakaian merek yang dapat dikategorikan persamaan pada pokoknya, yakni: ${ }^{15}$

1. Similarity in appearance (kemiripan dalam hal penampilan), yang dalam arti dapat membingungkan dalam bentuk penggambaran.

2. Similarity in sound (kemiripan bunyi/pengucapan), yang dalam arti dapat membingungkan dalam bentuk pengucapan.

3. Similarity in concept (kemiripan dalam konsep makna), di mana arti dalam suatu bentuk memiliki persamaan dalam pengucapan.

Terminologi "persamaan secara keseluruhan (identic) terkait dengan teori identitas ganda (double identity) diatur dalam Article 15 (1) dan Article 16 (1) TRIPs dan Article 5 (2) Paris Convention. Dalam Undang-Undang Merek tidak ada penjelasan mengenai arti dari istilah "persamaan secara keseluruhan". M. Yahya Harahap menyatakan bahwa: ${ }^{16}$ "persamaan pada keseluruhan adalah persamaan seluruh elemen. Persamaan yang demikian sesuai dengan doktrin entires similiar atau sama keseluruhan elemen."

Dengan kata lain, merek yang diajukan pendaftarannya merupakan salinan (copy) atau reproduksi merek orang lain. Merek dapat disebut copy atau reproduksi merek orang lain, jika mengandung persamaan secara keseluruhan paling tidak harus memenuhi syarat-syarat sebagai berikut: ${ }^{17}$

\footnotetext{
${ }^{13}$ Ok. Saidin,, Op Cit, hlm. 359

14 Ahmadi Miru, 2005, Hukum Merek: Cara Mudah Mempelajari Undang-Undang Merek. PT. RajaGrafindo Persada, Jakarta, hlm. 17

${ }^{15}$ Ibid., hlm. 360

${ }^{16}$ M. Yahya Harahap, 1996, Tinjauan Merek Secara Umum dan Hukum Merek di Indonesia Berdasarkan UU No. 19/1992, Citra Aditya Bakti, Bandung, hlm. 41-47. Lihat juga Rahmi Jened, 2015, Hukum Merek (Trademark Law) dalam Era Global dan Integrasi Ekonomi, Prenadamedia Group, Jakarta, hlm. 175

${ }^{17}$ Rahmi Jened, Op.Cit., hlm. 176
} 
a. Terdapat persamaan elemen secara keseluruhan termasuk elemen hurufnya;

b. Persamaan jenis atau produksi kelas barang dan jasa;

c. Persamaan wilayah dan segmen pasar;

d. Persamaan pelaku pemakaian; dan

e. Persamaaan cara pemeliharaan.

Secara sederhana kriteria merek yang memiliki persamaan secara keseluruhan (identical marks) ada, apabila tanda memiliki persamaan secara keseluruhan dengan merek dan diterapkan untuk produksi sejenis yang telah dilindungan lebih dahulu dan perbuatannya dapat dikatakan pemalsuan (counterfeiting). ${ }^{18}$ Selanjutnya, terminologi "persamaan pada pokoknya secara keseluruhan" atau "merek similiar" juga diatur dalam Article 15 (1) dan Article 16 (1) TRIPs dan Article 5 (2) Paris Convention.

Persamaan pada pokoknya adalah kemiripan yang disebabkan oleh adanya unsurunsur yang menonjol antara merek yang satu dan merek lain, yang dapat menimbulkan kesan adanya persamaan baik mengenai bentuk, cara penempatan, cara penulisan, atau kombinasi antara unsur-unsur ataupun persamaan bunyi ucapan terdapat dalam merekmerek tersebut. ${ }^{19}$

Suatu merek dianggap mempunyai "persamaan pada pokoknya" dengan merek lain ditentukan dengan patokan lebih luwes dibanding doktrin entires. Dalam arti "persamaan pada pokoknya" (similiar), dianggap terwujud apabila merek hampir mirip (nearly resembles) dengan merek orang lain berdasarkan: ${ }^{20}$ persamaan bunyi, persamaan arti dan persamaan tampilan.

Suatu merek mirip atau similiar erat kaitannya dengan konsep "a likelihood of confusion", faktor yang paling penting dalam doktrin ini ialah bahwa pemakaian merek yang memiliki "persamaan pada pokoknya" menimbulkan semacam persamaan membingungkan (a likelihood ofconfusion) atau menimbulkan persamaan asosiasi (likelihood of association) antara produsen yang terkait dengan merek tersebut, sehingga memiliki potensi menyesatkan (decieve) masyarakat konsumen. Konsumen

\footnotetext{
${ }^{18}$ Ibid

${ }^{19}$ Ahmadi Miru, Op.Cit. hlm. 16

${ }^{20}$ Rahmi Jened, Op.Cit. hlm. 182
} 
akan menganggap bahwa merek tersebut diproduksi oleh sumber yang sama dengan barang milik orang lain. ${ }^{21}$

Dalam Undang-Undang Merek, persamaan pada pokoknya diatur dalam Pasal 6 ayat (1) huruf (a) dan Pasal 90 Undang-Undang Merek. Sesuai Pasal 6 ayat (1) huruf (a) Undang-Undang Merek mengatur: 74

"Permohonan harus ditolak oleh Direktorat Jenderal apabila merek tersebut:

(a) Mempunyai persamaan pada pokoknya atau secara keseluruhannya dengan merek pihak lain yang sudah terdaftar lebih dahulu untuk barang dan/atau jasa yang sejenis.” 22

Sedangkan dalam Pasal 90 Undang-Undang Merek mengatur:

"Barangsiapa dengan sengaja dan tanpa hak menggunakan merek yang sama pada keseluruhannya dengan merek terdaftar milik pihak lain untuk barang dan/atau jasa yang sejenis yang diproduksi dan/atau diperdagangkan, dipidana dengan pidana penjara paling lama 5(lima) tahun dan/atau paling banyak denda 1 milliyar rupiah.” 23

Berdasarkan ketentuan TRIPs dan Paris Convention serta Undang-Undang Merek tersebut, maka merek harus memiliki daya pembeda (relative grounds) ditolak atau diterimanya pendaftaran merek.

Berbicara mengenai masalah merek erat kaitannya dengan persaingan tidak jujur (unfair competition). Bila pengusaha dalam bidang perusahaan yang sejenis bersamasama berusaha dalam daerah yang sama pula maka masing-masing dari mereka berusaha semaksimal mungkin untuk mendapatkan tempat di hati masyarakat konsumen secara kompetitif. Apabila persaingan itu sudah sampai pada suatu keadaan, dimana pengusaha yang satu berusahan menjatuhkan lawannya untuk keuntungan sendiri tanpa mengindahkan kerugian yang diterima oleh pihak lain, maka inilah titik awal dari keburukan suatu kompetitif yang menjurus pada pelanggaran hukum. ${ }^{24}$

Pelanggaran terhadap merek motivasinya adalah untuk mendapatkan keuntungan pribadi secara mudah dengan mencoba atau melakukan tindakan meniru atau memalsukan merek-merek yang sudah terkenal di masyarakat tanpa memikirkan hakhak orang lain yang hak-haknya telah dilindungi sebelumnya.

Adapun mengenai pelanggaran merek sebagai persaingan tidak jujur, Pasal 10 Konvensi Paris memuat ketentuan bahwa negara peserta Uni Paris terikat memberikan

\footnotetext{
${ }^{21}$ Ibid., hlm. 183

${ }^{22}$.Indonesia, Undang-undang No. 15 Tahun 2001 tentang Merek

23. Ibid

${ }^{24}$ Ok.Saidin, Op.Cit. hlm. 360
} 
perlindungan yang efektif agar tidak terjadi persaingan tidak jujur. Dalam ayat kedua Pasal 10 Konvensi Paris ditentukan bahwa tiap perbuatan yang bertentangan dengan "honest practices industrial and commercial matters" dianggap sebagai perbuatan persaingan tidak jujur. Sedangkan ayat ketiga menentukan tentang pelarangan semua perbuatan yang dapat menciptakan kekeliruan dengan cara apapun berkenaan dengan asal usul atau yang berkenaan dengan usaha-usaha industrial dan komersial dari seseorang pengusaha yang mengacaukan publik berkenaan dengan sifat dan asal usul dari suatu barang, termasuk peniruan merek. ${ }^{25}$

Kaidah peniruan merek sendiri diatur dalam Pasal 4 Undang-Undang Merek. Pasal 4 mensyaratkan bahwa seorang pemohon pendaftaran merek harus memiliki iktikad baik tanpa ada niat lain. Niat yang dimaksudkan adalah untuk membonceng, meniru, atau menjiplak ketenaran merek pihak lain. Niat tersebut terpenuhi jika berakibat kerugian pada pihak lain, menimbulkan kondisi persaingan curang, mengecoh atau menyesatkan konsumen. Lebih lanjut dalam penjelasan Pasal 4 Undang-Undang Merek dikemukakan contoh yang kemudian dikaitkan dengan konsep persamaan pada pokoknya dan konsep merek terkenal. ${ }^{26}$

Mengacu pada uraian di atas dapat dikatakan bahwa pelaku usaha tidak dapat mendaftarkan merek dengan niat untuk meniru ketenaran yang berakibat kerugian pada pihak lain, menimbulkan kondisi persaingan curang, mengecoh, atau menyesatkan konsumen, sebagaimana yang penulis telah kemukakan sebelumnya. Ciri khusus mengenai kaidah peniruan merek dalam pasal ini adalah adanya keterhubungan antara peniruan merek dengan konsep persamaan pada pokoknya atau keseluruhannya.

Apabila Pasal 4 Undang-Undang Merek dihubungkan dengan Pasal 7 UndangUndang Merek yang menetapkan bahwa permohonan pendaftaran merek diajukan kepada Direktorat Jenderal HKI, maka dapat dikatakan bahwa pasal ini juga memberikan beban kepada Direktorat Jenderal HKI untuk tidak melakukan pendaftaran terhadap permohonan merek yang dinilai tidak beriktikad baik. Dengan demikian, Direktorat Jenderal HKI menjadi penentu pertama apakah sebuah merek didaftarkan berdasarkan iktikad baik atau tidak oleh pemiliknya, dan demikian pula menjadi

\footnotetext{
${ }^{25}$ Ibid

${ }^{26}$ Indirani Wicaksono, Kaidah Hukum Mengenai Peniruan Merek Dalam UU No. 15 Tahun 2001 Tentang Merek (Bag. 1), http://www.thewicaksonos.info/kaidah-hukum-mengenai-peniruan-merekdalam-uu-no-15-tahun-2001-tentang-merek-bag-1.html, diakses 20 Maret 2018
} 
penentu apakah permohonan suatu merek dapat diterima atau tidak. Apabila setelah suatu merek terdaftar terjadi perbedaaan pendapat dengan merek yang yang telah lebih dahulu terdaftar, maka hakim yang kemudian akan menjadi penentu kedua apakah suatu merek didaftarkan atas iktikad baik atau tidak. ${ }^{27}$

Asas itikad baik (good faith) menurut Subekti merupakan salah satu sendi terpenting dalam hukum perjanjian. ${ }^{28}$ Selanjutnya Subekti berpendapat bahwa perjanjian dengan itikad baik adalah melaksanakan perjajian dengan mengandalkan norma-norma kepatutan dan kesusilaan. ${ }^{29}$ Kewajiban untuk melaksanakan kontrak berdasarkan itikad baik sudah diakui secara universal dalam prinsip hukum kontrak internasional. Pengakuan secara internasional tersebut terdapat konsideran Konvensi Wina 1969 dimana disebutkan: "The principles of free consent and of good faith and the pacta sunt servanda rule are universally recognized". Selain itu dalam UNIDROIT (The International Institute for the Unification of Private Law) Pasal 1.7. dinyatakan "each party must act in accordance with good faith and fair dealing in international trade" and "the parties may not exclude or limit their duty". ${ }^{30}$ Berdasarkan hal tersebut maka asas itikad baik merupakan prinsip universal yang wajib diterapkan pada setiap perjanjian. Dalam mendaftarkan Hak Keayaan Intelektual (HKI), Hak Merek merupakan hak yang bersifat khusus. Hak khusus tersebut pada dasarnya bersifat exclusive dan monopoli yang hanya dilaksanakan oleh pemilik hak, sedangkan orang lain tidak boleh untuk menggunakan tanpa seizin pemiliknya.Pendaftaran merek adalah merek hanya dapat didaftarkan atas dasar permintaan yang diajukan pemilik merek yang beritikad baik atau dikenal dengan prinsip Good Faith. Walaupun pemerintah telah memberlakukan prinsip itikad baik, mengatur tentang tata cara pendaftaran akan suatu merek yang harus ditolak dan tidak dapat didaftarkan serta perlindungan hukum terhadap pemilik merek terdaftar.

Prinsip itikad baik dalam mendaftarkan merek dagang terdapat dalam pasal 4 Undang-undang nomor 15 tahun 2001 yang berbunyi; "Merek tidak dapat didaftar atas dasar Permohonan yang diajukan oleh Pemohon yang beritikad tidak baik" dimana dalam penjelasannya dikatakan;

\footnotetext{
${ }^{27}$ Ibid

${ }^{28}$ Subekti, Pokok-Pokok Hukum Perdata, PT. Intermasa, Cet.XXVIII, Jakarta, 1996., hlm.41

${ }^{29}$ Ibid

${ }^{30}$ Cindawati, Prinsip Good Faith (Itikad Baik) dalam Kontrak Bisnis Internasional, Mimbar Hukum, Vol.26 No.2, Juni 2014, Universitas Gajah Mada,Yogjakarta,2014, hlm.191
} 
"Pemohon yang beriktikad baik adalah Pemohon yang mendaftarkan Mereknya secara layak dan jujur tanpa ada niat apa pun untuk membonceng, meniru, atau menjiplak ketenaran Merek pihak lain demi kepentingan usahanya yang berakibat kerugian pada pihak lain itu atau menimbulkan kondisi persaingan curang, mengecoh, atau menyesatkan konsumen. Contohnya, Merek Dagang A yang sudah dikenal masyarakat secara umum sejak bertahun-tahun, ditiru demikian rupa sehingga memiliki persamaan pada pokoknya atau keseluruhannya dengan Merek Dagang A tersebut. Dalam contoh itu sudah terjadi iktikad tidak baik dari peniru karena setidaktidaknya patut diketahui unsur kesengajaannya dalam meniru Merek Dagang yang sudah dikenal tersebut." 31

Undang-Undang dan atau BW tidak memberikan devinisi yang jelas dan tegas tentang itikad baik (to goeder trouw ; good faith). Terdapat beberapa devinisi tentang itikad baik, sebagai berikut :

1. Rumusan itikad baik menurut Black's Law Dictionary adalah :

" Good faith is an intangible and abstract quality with no technical meaning or statutory definition, and it compasses, among other things, an honest belief, the absence of malice and the absence of design to defraud or to seek an unconscionable advantage, and individual's personal good faith is concept of his own mind and inner spirit and, therefore, may not conclusively be determinded by his protestations alone .... In common usage this term is ordinarily used to describe that state of mind denoting honesty of purpose, freedom from intention to defraud, and generally speaking, means being faithful to one's duty or obligation". ${ }^{32}$

2. Dalam kamus Istilah Hukum Fockema Andreae Belanda - Indonesia menyatakan goede trouw adalah semangat yang menjiwai para peserta dalam suatu perbuatan hukum atau tersangkut dalam hubungan hukum. ${ }^{33}$

${ }^{31}$. Ibid, hlm. 192

32. Hanry Campbell Black, Black's Law Dictionary, $4^{\text {th }}$ Edition, St. Paul, Minnesota, USA, West Publishing Co, 1984

${ }^{33}$.N.E, Algra, et al, Kamus Istilah Hukum Fockema Andreae Belanda - Indonesia, Bina Cipta, Jakarta, 1983, hal.581 
3. Menurut Hoge Raad, dalam putusannya tanggal 9 Februari 1923 (Nederlandse Jurisprudentie) memberikan rumusan terhadap goede trouwadalah "volgens de eisen van redelijkheid and billijkheid" artinya itikad baik harus dilaksanakan menurut kepatutan dan kepantasan. ${ }^{34}$ P.L. Werry menerjemahkan redelijkheidadalah rasional, yaitu dapat diterima oleh nalar dan akal sehat, sedang billijkheid adalah patut dan adil. Dengan demikian redelijkheid en billijkheid, yaitu semua yang dapat dirasakan dan dapat diterima nalar dengan baik, wajar, dan adil. ${ }^{35}$

Berdasarkan devinisi diatas, maka itikad baik harus mengandung kewajaran, kepatutan, keadilan dan dapat diterima oleh nalar dan akal sehat. Itikad baik juga dapat diukur dengan norma-norma objektif, bukan hanya berasal dari subjektivitas para pihak. ${ }^{36}$

Kriteria penilaian itikad baik dapat dilakukan dengan penilaian yang bersifat relatif / subjektif dan penilaian yang bersifat absolut / objektif. Penilaian yang bersifat relatif dapat dilakukan dengan menilai tingkah laku yang nyata dari subyek. Sedangkan penilaian yang bersifat objektif dapat dilakukan dengan akal sehat dan keadilan. ${ }^{37}$ Oleh karenanya, hukum kontrak di Indonesia harus mengalami perubahan dengan merumuskan itikad baik secara jelas masuk dalam peraturan perundang-undangan hukum kontrak Indonesia. Sedangkan di Belanda pasal 6 : 248 (1) NBW telah menghapuskan istilah "geode trouw", pengertian itikad baik sebagaimana dimaksud dalam pasal 1338 (3) BW diartikan sebagai redelijkheid (reasonableness) dan billijkheid (equity)atau kepatutan dan keadilan. ${ }^{38}$

Berdasarkan penilaian itikad baik tersebut, maka Wirjono Projodikoro ${ }^{39}$ berpendapat bahwa pengertian itikad baik menurut pasal 1338 (3) BW adalah pengertian dalam arti objektif dan dinamis. Sehingga itikad baik disini bersifat dinamis yang melingkupi keseluruhan proses permohonan dan pendaftaran merek .Itikad baik dalam arti bersifat dinamis artinya juga bahwa pihak yang satu tidak

\footnotetext{
34. P.L. Werry, Perkembangan Hukum tentang Itikad Baik di Netherland, Percetakan Negara RI, Jakarta, 1990, hal.9

35. Ibid.

${ }^{36}$. Ibid.

${ }^{37}$. N.E, Algra, Op.cit, hal.580.

38 . P.L.Werry, Op.cit, hal.9

${ }^{39}$.Wirjono Prodjodikoro, Asas-Asas Hukum Perdata, Sumur, Bandung, 1992, hal.62.
} 
boleh merugikan pihak yang lain atau tidak boleh menggunakan kelalaian pihak lain untuk menguntungkan diri pribadi, karena kejujuran harus berjalan dalam hati sanubari pihak yang mengajukan permohonan dan pendaftaran merek .

Beberapa contoh putusan Mahkamah Agung dalam kasus merek yang terkait dengan pertimbangan hukumnya dengan prinsip itikad baik dalam pendaftaran merek di Indonesia.

1. Yurisprudensi Mahkamah Agung RI tanggal 16 Desember 1986 No. 220/PK/1996 mengenai perkara Nike memberi pertimbangan mengenai iktikad baik sebagai berikut:

"Bahwa warga negara Indonesia yang memproduksi barang-barang buatan Indonesia wajib menggunakan nama-nama merek yang jelas menampakkan identitas Indonesia dan sejauh mungkin menghindari menggunakan merek yang mirip, apalagi menjiplak merek asing, bahwa pendaftaran merek mempunyai persamaan pada pokoknya dengan merek orang lain yang lebih dahulu jelas merupakan perbuatan yang beriktikad buruk dengan tujuan membonceng pada keterangan nama perniagaan dan nama merek dagang yang terkenal itu." 40

2. Toyota dengan Mobil mewah Lexus menjadi perusahaan yang menggugat nama sejenis yang dipakai pihak lain. Dipimpin oleh Jidosha Kabushiki Kaisha, Lexus pernah menggugat Menara Lexus \& Gambar Menara daftar merek No. IDM000366409 tanggal 31 Agustus 2012, untuk melindungi: Jasa-jasa Hotel; Bahwa pemakaian Merek Dagang tersebut, yang mengandung kata LEXUS yang dalam ucapan kata maupun suara sama dengan LEXUS yang merupakan bahagian essential dari merek dagang MA mengamini permohonan Lexus sebagai pemilik merek tunggal. Jidosha Kabushiki Kaisha juga menggugat merek helm Lexus. Lagi-lagi, Toyota Lexus memenangkan dan sebagai pemegang hak ekslusif yang terdaftar sejak 25 Mei 1992 dengan registrasi No.275.609 yang diperbarui pada 25 Mei 2002.

${ }^{40}$ Rahmi Jened, Op. Cit.,hlm. 96. Lihat juga Tim Redaksi Tatanusa, 2008, Himpunan Putusanputusan Pengadilan Niaga dalam Perkara Merek, Jakarta, hlm. 108 
3. Kasus Ikea Swedia melawan PT. Ratania Khatulistiwa, hakim tidak mempertimbangkan mengenai iktikad baik dalam memutuskan perkara, walaupun dalam dalil yang diajukan oleh Ikea Swedia selaku Tergugat mengungkit mengenai pengajuan permohonan dengan iktikad tidak baik yang dilakukan oleh PT. Ratani Khatuliswa. ${ }^{41}$ Adapun dalam putusan Mahkamah Agung No. 264 K/Pdt.SusHKI/2015 tersebut didalikan sebagai berikut :

Berdasarkan perbandingan merek di atas, dalil-dalil menunjukkan kapasitas Termohon Kasasi sebagai pihak yang berkepentingan untuk menggunakan merek 'ikea' dengan maksud 'membawa manfaat bagi perekonomian nasional Indonesia', tindakan Termohon Kasasi dalam menggunakan serta mendaftarkan merek yang jelas memiliki persamaan pada pokoknya dengan merek terkenal, dalam hal ini Merek 'IKEA' milik Pemohon Kasasi, justru menunjukkan iktikad Termohon Kasasi yang bermaksud mendompleng keterkenalan Merek 'IKEA' Pemohon Kasasi. Lebih lanjut, adanya gugatan penghapusan yang diajukan oleh Termohon Kasasi, justru merupakan suatu bentuk pengakuan dari Termohon Kasasi, bahwa permohonan pendaftaran merek 'ikea' Termohon Kasasi yang diajukan kepada Turut Termohon Kasasi, memiliki persamaan pada pokoknya dengan pendaftaran merek 'IKEA' milik Pemohon Kasasi, yang telah terdaftar dan digunakan di banyak negara di dunia, termasuk di Indonesia, jauh sebelum Termohon Kasasi mengajukan permohonan pendaftaran merek 'ikea' Termohon Kasasi kepada Turut Termohon Kasasi. Oleh karenanya, sebagaimana telah Pemohon Kasasi kemukakan sebelumnya, sangat beralasan apabila permintaan pendaftaran merek-merek 'IKEA' Termohon Kasasi diajukan tanpa iktikad baik.

Pada permohonan tersebut sudah sangat jelas merek 'ikea' milik PT. Ratania Khatulistiwa didaftarkan tanpa iktikad baik karena bermaksud meniru dan membonceng keterkenalan merek "IKEA" milik Inter Ikea BV, akan tetapi pada akhirnya hakim Syamsul Ma'arif tidak mempertimbangkan hal tersebut dan pada akhirnya merugikan pihak Inter Ikea BV.

Dengan karenanya, permohonan penghapusan merek terdaftar oleh pihak ketiga yang memiliki merek yang mempunyai kesamaan pada keseluruhannya dengan merek yang terdaftar sesuai dengan sengketa merek 'IKEA' melawan 'ikea' milik PT. Ratania

\footnotetext{
${ }^{41}$ Putusan Mahkamah Agung Nomor 264. K/Pdt.Sus-HKI/2015, hlm.16
} 
Khatulistiwa Surabaya yang akhirnya dimenangkan oleh PT. Ratania Khatulistiwa menjadi pendaftaran merek dagang baru yang oleh satu pihak dengan merek dagang terkenal yang didaftarkan terlebih dahulu milik pihak lain. Suatu merek baru seharusnya akan ditolak pendaftarannya jika memiliki persamaan pada pokoknya (mirip) atau persamaan secara keseluruhan (identik) dengan merek yang telah terdaftar terlebih dahulu yang dimana diatur dalam Pasal 6 Undang-Undang Merek.

\section{SIMPULAN}

Prinsip itikad baik dalam pendaftaran merek dagang terdapat dalam pasal 4 Undang-undang nomor 15 tahun 2001 yaitu merek tidak dapat didaftarkan atas dasar permohonan yang diajukan oleh Pemohon yang beritikad tidak baik. Sehingga dalam pengajuan permohonan pendaftaran merek dan merek terkenal harus dilakukan dengan itikad baik, dalam arti itikad baik disini bersifat dinamis yang melingkupi keseluruhan proses permohonan dan pendaftaran merek. Itikad baik dalam arti bersifat dinamis artinya juga bahwa pihak yang satu tidak boleh merugikan pihak yang lain atau tidak boleh menggunakan kelalaian pihak lain untuk menguntungkan diri pribadi, karena kejujuran harus berjalan dalam hati sanubari pihak yang mengajukan permohonan dan pendaftaran merek.

\section{DAFTAR PUSTAKA}

\section{Buku :}

Astarini, Dwi Rezki Sri. 2009. Penghapusan Merek Terdaftar Berdasarkan UU No. 15 Tahun 2001 Tentang Merek Dihubungkan Dengan TRIPs-WTO, Alumni, Bandung.

Black, Hanry Campbell. 1984. Black's Law Dictionary, $4^{\text {th }}$ Edition, St. PaulMinnesota, USA: West Publishing Co

Cindawati. 2014.Prinsip Good Faith (Itikad Baik) dalam Kontrak Bisnis Internasional Mimbar Hukum, Vol.26 No.2, Yogyakarta : Universitas Gajah Mada

Harahap, M. Yahya. 1996.Tinjauan Merek Secara Umum dan Hukum Merek di Indonesia Berdasarkan UU No. 19/1992, Bandung : Citra Aditya Bakti

Jened, Rahmi. 2015.Hukum Merek (Trademark Law) Dalam Era Global \& Integrasi Ekonomi, Jakarta: Kencana

Jened, Rahmi. 2015.Hukum Merek (Trademark Law) dalam Era Global dan Integrasi Ekonomi, Jakarta : Prenadamedia Group 
Jened, RahmiOpCit. 2008., Himpunan Putusan-putusan Pengadilan Niaga dalam Perkara Merek, Jakarta :Tim Redaksi Tatanusa

Miru, Ahmadi. 2005.Hukum Merek: Cara Mudah Mempelajari Undang-Undang Merek,Jakarta : PT. RajaGrafindo Persada

M. Ramli, Ahmad. 2010.Hak atas Kekayaan Intellectual (HAKI), Teori Dasar Perlindungan Rahasia Dagang, Bandung:Mandar Maju

N.E, Algra, et al. 1983.Kamus Istilah Hukum Fockema Andreae Belanda - Indonesia, Jakarta: Bina Cipta

Prodjodikoro, Wirjono. 1992. Asas-Asas Hukum Perdata, Bandung: Sumur

Saidin, Ok. 2013.Aspek Hukum Hak Kekayaan Intelektual (Intellectual Property Rights),Jakarta:PT. RajaGrafindo Persada

Subekti. 1996. Pokok-Pokok Hukum Perdata (Cet.XXVIII), Jakarta : PT. Intermasa

\section{Jurnal :}

Jisia Mamahit, "Perlindungan Hukum Atas Merek Dalam Perdagangan Barang Dan Jasa”, http://ejournal.unsrat.ac.id/index.php/lexprivatum/article/, diakses tanggal 23 November 2017

\section{Internet:}

Indirani Wicaksono, "Kaidah Hukum Mengenai Peniruan Merek Dalam UU No. 15 Tahun 2001 Tentang Merek (Bag. 1)”,http://www.thewicaksonos.info/kaidahhukum-mengenai-peniruan-merek-dalam-uu-no-15-tahun-2001-tentang-merek-

$\begin{array}{lllll}\text { bag-1.html, } & \text { diakses } & \text { tanggal } & 20 & \text { Maret }\end{array}$

PrayudiSetiadharma, "Sedikit Kisah Mengenai Tentang Hapusnya Merek IKEA", http://www.hki.co.id/artikel, diakses tanggal 20 Maret 2018

\section{Peraturan Perundang-undangan :}

Undang-undang No. 15 Tahun 2001 tentang Merek 